J. Perinat. Med. 6 (1978) 165

\section{Comparative study of serum CAP activity during pregnancy in malformed and normal uterus}

\author{
Martin Blum
}

Department of Obstetrics and Gynecology, Hasharon Hospital, Petah-Tiqva, and Tel Aviv University Medical School, Israel
Fetus monitoring in all its uterine development stages is of major importance in perinatology, in order to avoid spontaneous abortions, intrauterine growth retardation and prematurity or perinatal mortality as a result of respiratory distress syndrome.

Among the many available methods for fetal monitoring (ultrasonography, hormone tests a.s.o.), the examination of the different enzymes' activity in serum, urine and amniotic fluid is an accurate index of the feto-placental unit function.

The serum CAP activity during normal and pathological pregnancies was studied in many works to date. In contrast, there are no reports on the enzymatic activity in pregnancy in malformed uteri.

The aim of the present study is to investigate the activity of cystine aminopeptidase (CAP) during pregnancy in malformed uteri in comparison with that in normal uteri.

\section{Material and Methods}

The investigations were conducted in a group of 82 pregnant women between 20 and 31 years of age, with congenital or acquired uterine malformations, with a poor obstetrical history. This group of patients comprised: 23 women with uterus bicornus, 5 with uterus dydelphis, 2 with uterus duplex, 13 with uterus arcuatus, and 1 with uterus unicornis. We have included in our study also the cases of so-called "acquired" malforma-

\section{Curriculum vitae}

MARTIN BLUM, M.D. graduated of the Bucharest Medical School. Since 1961 he joined the Hasharon Hospital staff, in the Department of Obstetrics and Gynecology, at that time under the direction of Prof. I. Halbrecht. He works now in the same Hospital as chief physician. He is also lecturer at the Tel Aviv University Medical School, member of the Deutsche Gesellschaft für Geburtshilfe und Gynäkologie and a fellow of the International College of Surgeons and of Gestosis Organisation. His major interest is the study of the placentar enzymes in perinatology and gynecologic cancer.

tions, namely 7 women with uterus myomatosus and 31 with intrauterine adhesions. In the patients' past there were 145 second trimester abortions and 9 premature deliveries with children who developed respiratory distress syndrome. None of the women ever delivered a viable child.

During the whole period of pregnancy, we have examined the serum CAP in all patients, according to the method of BABUNA and YeNEN [2], the results being read on the colorimeter and expressed in optical density units. These results were compared to those obtained by us in a previous study in a number of 65 women belonging to a comparable group of age and with normal pregnancy in a normal uterus [4]. 
Tab. I. Statistical data (NS : not significant, S: significant)

\begin{tabular}{lllllllll}
\hline Weeks of pregnancy 5 & 10 & 15 & 20 & 25 & 30 & 35 & 40 \\
\hline$t$ value & 0.31 & 1.53 & 0.67 & 1.11 & 2.37 & 2.33 & 2.06 \\
P (t) & $2 \mathrm{P}>0.05$ & $2 \mathrm{P}>0.02$ & $2 \mathrm{P}>0.02$ & $2 \mathrm{P}>0.05$ & $2 \mathrm{P}<0.05$ & $2 \mathrm{P}<0.05$ & $2 \mathrm{P}<0.05$ & - \\
& $\mathrm{NS}$ & $\mathrm{NS}$ & $\mathrm{NS}$ & $\mathrm{NS}$ & $\mathrm{S}$ & $\mathrm{S}$ & $\mathrm{S}$ & \\
\hline
\end{tabular}

\section{Results}

The serum activity of CAP is decreased in all cases of malformed uterus, especially beginning with the second trimester of pregnancy. These results are presented on the Tab. I, where the statistical data processed by means of the "Student test T" are recorded.

The CAP activity is significantly decreased $(2 \mathrm{P}<$ 0.05 ) as compared to that in normal pregnancies. The serum enzymatic values obtained in our study are higher than those obtained by using the kinetic method for serum CAP determination, described by Oudheusden [12]. This new method, using as substrate S-benzyl-L-cysteine-p-nitroanilide, can reduce the assay time and therefore seems to be more suitable.

\section{Discussion}

Almost all the authors agree nowadays that the examination of the enzymatic activity, and especially of the enzymes belonging to the aminopeptidase group, may be of great help in perinatology $[1,5,6,8,9,13]$, and moreover in combination with the parallel tests of the urinary estrogen excretion $[9,10]$. These tests are of major importance in cases of pathological pregnancies and in patients with high risk pregnancies.

As it is very well known, CAP has the quality to decompose the hypophisar oxytocin. This is the situation in normal uteri, but the decreased CAP activity in malformed uteri raises some questions.
BENGTSSON [3] described the activity of a double, nonpregnant uterus, and HEIN et al [10] the motility of the malformed, nonpregnant uterus. According to these authors' views, there is a dissociation of the myometrial reactivity. In all recordings both hemi-uteri reacted in the same way, but not simultaneously, to the same stimuli. If this occurs in nonpregnant malformed uteri, it may be assumed that in pregnant malformed uteri the situation presents itself in a more drastic way, moreover so as the serum CAP activity is decreased and cannot neutralize the hypophisar oxytocin. This fact may result in uncoordinated uterine contractions to which the uterine cervix being not able to resist, can terminate in spontaneous abortions or premature deliveries. Even if the pregnancy is not eliminated, the contractions may result in placental micro-ablations, ending by placental insufficiency together with the intrauterine growth retardation of the fetus.

From the results of our work, we may clearly conclude that in cases of uterine malformations, congenital or acquired, the serum CAP activity is decreased. Therefore, in all cases of uterine malformation, although with a normal cervix, but in which serum CAP activity is diminished as compared to the normal value, it is suggested to perform a cervical suture in order to avoid second trimester abortions or perinatal mortality, as a result of prematurity or respiratory distress syndrome.

In all 82 cases in which we have performed cerclage, the pregnancies terminated by deliveries of viable fetuses weighting from 2670 to $3950 \mathrm{gr}$.

\section{Summary}

The serum activity of cystine aminopeptidase (CAP) was investigated during pregnancy in malformed uteri in comparison to that in normal uteri. The investigations were conducted in 2 groups of women: the first consisted of 82 pregnant women between 20 and 31 years of age

with congenital or acquired uterine malformations diagnosed by hysterography and in whom all previous pregnancies ended by second trimester abortion or premature delivery. The second group comprised 65 pregnant women with normal pregnancy in a normal uterus. 
Our results revealed that CAP activity is more decreased in cases of pregnancies in malformed uteri as compared to that in normal uterus, especially beginning from the second trimester of pregnancy. The decreased CAP activity cannot neutralize the hypophisar oxytocin, thus causing unco-ordinated contractions of the pregnant malformed uterus which may transform the pregnancy in a high risk pregnancy resulting in spontaneous abortions or premature deliveries.

The only means to avoid these complications is to perform cerclage in all cases of pregnancy in a malformed uterus, although with normal cervix, and a poor obstetrical history.

Keywords: Cystine aminopeptidase, pregnancy, uterine malformation

\section{Zusammenfassung}

Vergleichende Untersuchung über die Cystin-AminoPeptidase in der Schwangerschaft bei miBgebildeten und normalen Uteri.

Bei Schwangeren mit Uterus-Mißbildungen wurde die Cystin-Amino-Peptidase im Serum (CAP) untersucht und mit den Werten bei normaler Schwangerschaft verglichen. Unser Kollektiv bestand aus zwei Gruppen. Die erste umfaßt 82 Schwangere im Alter von 20-31 Jahren mit angeborenen oder erworbenen Uterus-Fehlbildungen. Die Art der Mißbildung war zuvor durch Hysterographien verifiziert worden. Alle früheren Schwangerschaften dieser Patientinnen endeten durch Abort im mittleren Trimenon oder als Frühgeburt. Die zweite Gruppe enthält 65 Schwangere mit normalem Uterus.
Unsere Untersuchungen zeigen, daß die Serum-CAP-Aktivität im miBgebildeten Uterus erniedrigt ist - besonders ab zweitem Schwangerschaftsdrittel. Wir nehmen an, daß die erniedrigte CAP-Aktivität das hypophysäre Oxitozin nicht neutralisieren kann und es dadurch $z u$ unkoordinierten Kontraktionen im mißgebildeten Uterus kommt. Die Folge ist möglicherweise eine Risikogravidität mit der Gefahr der vorzeitigen Beendigung durch Abort oder Frühgeburt.

Die einzige Methode zur Verhütung dieser Komplikation ist die Cerclage, die in allen Fällen von Uterus-Mißbildung durchgeführt werden sollte, auch wenn der Zervix-Befund normal ist und die Anamnese auf eine vorzeitige Schwangerschaftsbeendigung schließen läßt.

Schlüsselwörter: Schwangerschaft, Uterus-Mißbildung, Cystin-Aminopeptidase.

\section{Résumé}

Etude comparative de l'activité de la CAP du sérum en cours de grossesse dans les utérus normaux et malformés

Le présent article porte sur l'étude comparative de l'activité de l'aminopeptidase de cystine (CAP) du sérum en cours de grossesse dans des utérus normaux et malformés.

Deux groupes de parturientes avaient été sélectionnés à cet effet: Le premier se composait de 82 femmes enceintes âgées de 20 à 31 ans et chez lesquelles on avait diagnostiqué par hystérographie des malformations utérines congénitales ou acquises et dont toutes les grossesses antérieures s'étaient terminées par un avortement spontané au second trimestre ou un accouchement prématuré. Le second groupe réunissait 65 femmes enceintes ayant un utérus et une grossesse normaux.

Mots-clés: Aminopeptidase de cystine, grossesse, malformation utérine
Nos résultats ont montré que l'activité de CAP baisse davantage dans les cas de grossesse dans un utérus malformé, surtout à partir du deuxième trimestre de gravidité, L'activité ralentie de CAP ne peut pas neutraliser l'oxy tocine hypophisaire, provoquant ainsi des contractions non coordonnées de l'utérus malformé enceint avec, pour conséquence, la transformation de la gravidité en grossesse à haut risque et le déclenchement d'un avortement spontané ou d'un accouchement prématuré.

Le seul moyen d'éviter ces complications est d'appliquer un cerclage dans tous les cas de grossesse dans un utérus malformé même si le cervix est normal et si l'anamnèse obstétrique est «chargée».

\section{Bibliography}

[1] ANCES, I. G.: Observations on the level of blood oxytocinase throughout the course of labor and pregnancy. Amer. J. Obstet. Gynecol. 113 (1972) 291

[2] BABUNA, C., E. YENEN: Enzymatic determination of placental function. Amer. J. Obstet. Gynecol. 95 (1966) 925

[3] BENGTSSON, L. P.: Myometrial activity in a double, nonpregnant human uterus. Acta Obstet. Gynec. Scand. 49 (1970) 13
[4] BLUM, M., S. WOLKOWISKY, R. MENACHE, I. HALBRECHT: Oxytocinase in normal and pathological pregnancies. Harefuah 81 (1971) 167

[5] BLUM, M., F. SHABTAY, I. HALBRECHT: Relationship between postpartum serum oxytocinase levels and afterpains. Harefuah 88 (1975) 316

[6] BLUM, M., E. COHEN, F. SHABTAY, I. HALBRECHT: L'ocytocinase du liquide amniotique. Dosage et origine dans les grossesses normales et 
pathologiques. Rev. Fr. Gynec. Obstet. 70 (1975) 635

[7] BLUM, M., I. HALBRECHT: Uterine malformation as indication for cerclage in habitual abortion. The Family Physician 5 (1975) 203

[8] CHAPMAN, L., R. BURROWS-PEAKIN, V. P. REGE, E. SILK: Serum cystine aminopeptidase and the normal weight baby in normotensive and hypertensive pregnancy. Brit. J. Obstet. Gynec. 82 (1975) 278

[9] CURZEN, P., R. VARMA: A comparison of serum cystine aminopeptidase and urinary estrogen excretion as placental function tests. Amer. J. Obstet. Gynecol. 115 (1973) 929

[10] HeIN, P. P., L. A. M. STOLTE, T. K. A. B. ESKES, J. JANSSENS, J. T. BRAAKSMA, E. B. KARS-
VILlanUeVA, J. J. VAN DER HARTEN, P. A. DE JONG: The motility of the nonpregnant congenitally malformed uteru'. Europ. J. Obstet. Gynec. Reprod. Biol. 4 (1974) 51

[11] KLEINER, H., VI.STAVRIC, M. BR̃OUET-YAGER, J. SCHWERS, G. L. A. GRAFF: Mesure de l'«oxytocinasê» plasmatique. Comparaison avec l'excrétion urinaire des oestrogènes. J. Gynec. Obstet. Biol. Repr. 5 (1976) 25

[12] OUDHEUSDEN, A. P. M.: Kinetic determination of serum oxytocinase using a new substrate. Z. Klin. Chem. Klin. Biochem. 10 (1972) 345

[13] USATEGUI-GOMEZ, M., P. TARBUTTON, F. YEAGER: A colorimetric assay for oxytocinase in pregnancy serum. Clin. Chim. Acta 47 (1973) 409

Received July 1, 1976. Revised April 9, 1978. Accepted April 17, 1978.

Martin Blum, M.D., F. I. C. S.

Department Ob-Gyn,

Hasharon Hospital

Petah-Tiqva

Israel 